\title{
El alba de una revolución. La izquierda y el proceso de construcción estratégica de la "vía chilena al socialismo" 1956-1970
}

\author{
Marcelo Casals Araya, LOM Ediciones, Santiago 2010, 290 páginas. \\ Jorge Gaete Lagos $\left(^{*}\right)$
}

El 11 de septiembre de 1973 representa un día trascendental para la historia reciente de nuestro país, debido a que el gobierno de Salvador Allende sucumbió ante la acción concertada de las Fuerzas Armadas y de Orden. Esto marcó el inicio de una larga dictadura militar que comandó Augusto Pinochet, la que se destacó por la represión ejercida hacia los grupos opositores al régimen, y también por la implantación de un modelo económico neoliberal, el cual sobrevivió luego del retorno a la democracia y se mantiene en la actualidad.

Los orígenes y la elaboración que tuvo el truncado plan de la izquierda corresponden al eje central del presente libro, cuyo período de análisis está centrado entre los años 1956 y 1970. A lo largo de sus páginas, Marcelo Casals aborda la historia políticoideológica de la izquierda marxista chilena, y pone énfasis en las convergencias y discrepancias que tuvo ese sector político a la hora de preparar este proyecto, el que buscaba erradicar el capitalismo e instaurar el socialismo, a través de una "revolución" que pretendía remecer las bases estructurales de nuestro país.

En el primer apartado del texto, Casals se centra en las reformulaciones que vivió la izquierda entre 1956 y 1962. Aquí destaca que la década de 1950 marcó la reunificación del trajo Partido Socialista (PS), gracias a que el Partido Socialista de los Trabajadores y el Partido Socialista Auténtico pasaron a integrar sus filas. Junto a esto, menciona que años después, el Partido Socialista Popular se incorporó posteriormente a la colectividad, luego de retirarse del gobierno de Carlos Ibáñez del Campo.

También señala que el PS estableció conversaciones con el Partido Comunista (PC) y con otras agrupaciones que representaban a la clase trabajadora para llevar a cabo el proyecto, lo que provocó el nacimiento del Frente Nacional del Pueblo (FRENAP) en

$\left(^{*}\right)$ Magíster (c) en Historia, Universidad Nacional Andrés Bello. 
1955, como una manera de ampliar el antiguo Frente del Pueblo que apoyó a Salvador Allende en las elecciones presidenciales de 1952. Casals destaca que a pesar de que en aquella oportunidad Allende consiguió una baja votación, poco a poco se fue transformando en un destacado líder de la izquierda nacional.

A su vez, resalta que a partir de esa época el PC buscó generar alianzas con grupos como la Democracia Cristiana (DC) y el Partido Radical (PR) porque consideraba que en esas colectividades existían facciones que compartían con ellos algunas de sus ideas revolucionarias. Este carácter "electoralista" y el permanente apego que mostraron los comunistas al sistema democrático, provocó la existencia de corrientes revolucionarias mucho más radicales en el seno del Partido, como la de Luis Reinoso, lo que generó fracturas internas constantes.

Más adelante, Casals indica que el PS consideraba que el PC era un aliado fundamental para hacer la revolución, aunque ambos tenían diferencias en los ámbitos discursivo y estratégico. Entre éstas, se menciona que los socialistas manifestaron una constante posición antiburguesa y antisistémica, lo que causó su rechazo a la idea comunista de aliarse con el PR por considerar que este grupo estaba compuesto de miembros de la burguesía, y también hubo reticencias por los rencores existentes luego de las medidas que había tomado en su época el gobierno de Gabriel González Videla.

A pesar de que al interior de la izquierda se reconocía la existencia de este tipo de desavenencias, en 1956 nació el Frente de Acción Popular (FRAP), con lo cual la izquierda comenzó a ganar espacio en el esquema electoral del país y en la sociedad, e incluso estuvieron muy cerca de conseguir el triunfo en las elecciones presidenciales de 1958. Por otro lado, el autor señala que los Partidos más importantes del FRAP circularon por caminos ideológicos distintos, debido a que el PC siguió la línea denominada como "Frente de Liberación Nacional", la que implicaba que debían acceder al poder mediante alianzas con grupos que estuviesen de acuerdo con las ideas marxistas, sin importar su procedencia, mientras que el PS se inclinó por el "Frente de Trabajadores", ya que buscaba aliarse exclusivamente con los Partidos de clase obrera.

En conjunto a esto, se destaca en el libro que el PS le criticó al PC su excesivo electoralismo, y también le reprochó su apego a la causa liderada por la Unión Soviética. De hecho, el PC adoptó la tesis de la "vía pacífica al socialismo" que se expuso en el XX Congreso de la URSS en 1956, en cuya ocasión se dijo que Stalin fue una desviación de la doctrina marxista, y se atacó al maoísmo, porque buscaba integrar elementos militares a la revolución. Sin embargo, en Latinoamérica surgieron grupos guerrilleros como las FARC colombianas y el Sendero Luminoso en Perú.

En la segunda parte de su libro, Marcelo Casals nos habla sobre las derrotas y los conflictos de la izquierda entre 1962 y 1967 . Comienza resaltando que en las elecciones de 1964 hubo una convergencia sistémica de este sector en torno a la candidatura de Salvador Allende, a la cual se le buscó dar tintes revolucionarios para integrar a otros sectores. También menciona que la opción sistémica que siguieron los comunistas 
El alba de una revolución. La izquierda y el proceso de construcción estratégica de la "vía chilena al socialismo" 1956-1970

Marcelo Casals Araya, Lom Ediciones, Santiago, 2010, 290 páginas

se consideró viable luego del "Naranjazo" de ese mismo año, ocasión en la que el socialista Oscar Naranjo Arias resultó elegido como diputado con una inesperada alta votación en la provincia de Curicó, luego de la muerte de su padre Oscar Naranjo Jara.

Si bien el clima parecía favorable a la izquierda, el apoyo que la derecha le brindó en 1964 a la candidatura de Eduardo Frei Montalva provocó una nueva derrota para el FRAP. Esto desencadenó una serie de cuestionamientos internos al interior del PS, aunque el PC culpó a las fallas funcionales que hubo en la campaña y se mantuvo firme en la línea sistémica, porque consideraban al Parlamento como la instancia idónea para exponer los dilemas de la clase trabajadora.

Otro elemento que se señala en el texto, corresponde a las corrientes rupturistas de ultraizquierda que se formaron en esos años. Entre estas, el autor resalta a la Vanguardia Revolucionaria Marxista (VRM), cuyo período de formación fluctuó entre 1957 y 1963. A partir de esta agrupación, se formó en 1967 el Movimiento de Izquierda Revolucionaria (MIR), el que radicalizó aún más la postura al plantear que la instauración del socialismo debía ser mediante la vía armada.

Luego de abordar todos estos temas, el autor indica que a pesar de que la DC tuvo algunos triunfos durante los primeros años del mandato de Frei, especialmente en las elecciones parlamentarias de 1966, con el paso del tiempo aumentaron las críticas de la izquierda hacia el gobierno, por las medidas represivas que aplicó en algunas huelgas y por los pocos resultados que trajo la "revolución en libertad". Ese descontento provocó el surgimiento de fuerzas terceristas al interior de la DC, las que se acercaron paulatinamente a la izquierda chilena.

En la última sección del libro, el autor aborda las contradicciones e inconsistencias que tuvo el proyecto revolucionario entre 1967 y 1970. En este apartado, destaca que a pesar de las discrepancias que tuvieron el PC y el PS, este último optó por aliarse con otros Partidos y por seguir la vía sistémica, ya que consideró que estas opciones eran, en ese entonces, las únicas alternativas viables para aplicar un régimen socialista, a pesar de que su línea revolucionaria fue reafirmada en su Congreso de Chillán de 1966. Gracias a esto, se formó la Unidad Popular, la que estuvo compuesta por partidos como el PR y el Movimiento de Acción Popular Unitaria (MAPU), que provenía de la DC. Si bien la Democracia Cristiana estuvo cerca de integrarse al proyecto izquierdista, ellos optaron por seguir un camino propio al elegir a Radomiro Tomic como abanderado en las elecciones de 1970, año en que Allende resultó electo como Presidente de Chile luego de la firma de un Estatuto de Garantías Democráticas que la DC le propuso a la UP ante lo estrecho de esas elecciones.

El autor concluye su libro indicando que la vía revolucionaria de Allende buscaba una transición pacífica hacia el socialismo, equilibrando las posiciones que había al interior de la izquierda chilena, y también buscaba alejarse de términos marxistas, como el de la "dictadura del proletariado" por ejemplo. Sin embargo, las falencias teóricas que poseían los Partidos, y el fraccionamiento interno que tuvo la UP, provocaron el 
posterior fracaso del proyecto izquierdista.

A grandes rasgos, cabe destacar que el presente trabajo destaca por su alto nivel de análisis, y especialmente por abordar un tema que ha sido tabú para muchos historiadores de nuestro país, los que han argumentado que el quiebre institucional de 1973 es un tema reciente como para abordarlo, y han criticado que este tipo de investigaciones pueden distorsionarse por mostrar el color político de los autores. Quizá ese sea el mayor mérito de Marcelo Casals, ya que a pesar de reconocer su militancia izquierdista, critica sin inconvenientes a ese sector político por las falencias que tuvo su proyecto y que le costó el derrocamiento a Salvador Allende, con lo cual logra instalarse en el verdadero sitial que debe ocupar el historiador frente a este tipo de sucesos.

En definitiva, este libro permite conocer de manera profunda los orígenes del inconcluso plan que tuvo la izquierda para nuestro país, y que acabó de manera violenta con la llegada de la dictadura militar. 